\title{
Evaluation of the effects of some agroforestry practices on selected properties of soils in a sub- humid zone of Ghana
}

\author{
I. TETE-MENSAH, G. N. DOWUONA, S. G. K. ADIKU \& M. BONSU \\ (I. T.-M., G. N. D. \& S. G. K. A.: Department of Soil Science, University of Ghana, Ghana; M. B.: \\ Department of Soil Science, University of Cape Coast, Cape Coast, Ghana)
}

\section{SUMMARY}

The study investigated the effects of three 5-year-old cropping systems comprising Leucaiena hedgerows with cowpea (Vigna unguiculata), maize (Zea mays L.), and groundnut (Arachis hypogaea) on the accumulation of soil organic carbon, bulk density, porosity, and aggregate stability; and compared these with soils under a Leucaena woodlot of similar age in a forest-savanna transition zone of Ghana. The woodlot soils had the highest accumulation of organic carbon and total porosity. The aggregate stability in this system was more than twice the values for the alley cropping systems. Furthermore, the aggregate stability correlated well with the soil organic matter ( $r=0.77^{* *}$ ), suggesting that it can be well estimated from organic matter content. Among the three alley cropping systems, the accumulation of organic carbon was in the order cowpea $>$ maize $>$ groundnut, but the aggregate stability did not show any consistent pattern with organic matter content in these systems. The results indicated that despite the periodic addition of organic matter from pruned Leucaena hedgerows to the soil, the alley system did not improve the aggregate stability as much as the woodlot system.

Original scientific paper. Received 7 Jan 98; revised 23 Aug 99.

\section{Introduction}

Degradation of soils usually begins with the removal of the vegetative cover due to overgrazing, wood-cutting, and other agricultural practices such as fire and conventional tillage

\section{RÉSUMÉ}

Tete-Mensah, I., Dowuona, G. N., Adiku, S. G. K. \& Bonsu, M.: Evaluation des effets de quelques pratiques agroforestières sur les propriétés des sols selectionnées de la zone sous-humide du Ghana. Nous avons fait une enquête des effets de trois systèmes de culture ayant l'âge de 5 ans, comprenant les haies de Leucaena avec la dolique (Vigna unguiculata), le mais (Zea mays L.) et l'arachide (Arachis hypogea) sur l'accumulation du carbone organique de sol, la densité de masse, la porosité et l'agrégat de stabilité et nous avons comparé ces avec les sols de parcelle boisée de Leucaena d'âge pareille dans une zone de transition de la forêt-savane du Ghana. Les sols de la parcelle boisée avaient l'accumulation de carbone organique et la porosité totale les plus élevées. L'agrégat de stabilité dans ce système était plus que deux fois des valeurs obtenues pour les systèmes de la culture d'allée. En plus, l'agrégat de stabilité corrélait bien avec les matières organiques du sol $(r=0.77)$, suggérant qu'il pourrait être bien estimé du contenu de la matière organique. Parmi les trois systèmes de la culture d'allée l'accumulation du carbone organique était dans l'ordre de dolique > maïs > arachide mais l'agrégat de stabilité n'a pas montré aucun modèle en accord avec le contenu de la matière organique dans ces systèmes. Les résultats indiquaient que malgré l'augmentation périodique de la matière organique par les hajes de Leucaena taillées aux sols; le système d'allée n'a pas améloiré l'agrégat de stabilité autant que le système de parcelle boisée.

(Weert \& Lenselink, 1972). Tooffset degradation, various agronomic methods have been proposed including cover cropping, manuring and mulching. The traditional system of shifting cultivation has also conserved the soil by allowing long periods 
of fallow for the regeneration of soil fertility in between cultivation. However, this practice is losing popularity due to the ever-increasing population and pressure on land which shorten the fallow periods considerably.

In recent times, alley farming, a form of agroforestry, has been suggested as an attractive alternative to shifting cultivation and other forms of agricultural practices which in the past were adopted to combat soil degradation. Alley cropping is an agroforestry system developed in Java where prunings of leguminous trees such as Leucaena leucocephala grown in rows were used as mulch and source of nutrients for annual crops. It is reported that growing of trees, as in agroforestry, also plays a significant role in reducing runoff and erosion; hence, it prevents the deterioration of soil physical properties, since the forest canopy intercepts and reduces raindrop impact on the soil (Nair, 1984). The incorporation of woody perennials into cropping systems could, therefore, provide a regulatory effect to limit the intensity of deterioration of cultivated soils (Dowuona et al., 1998).

Despite the potential attractions of alley farming systems, the adoption rate by farmers in Ghana is low, probably due to intensive labour requirements and the fact that the parcel of land occupied by the trees is unavailable for the production of annual crops. Furthermore, detailed empirical data on the effects of alley cropping on soil properties in Ghana are lacking.

This study, therefore, aimed at investigating the relative effects of alley cropping systems and a woodlot on some selected soil properties, 5 years after their establishment.

\section{Materials and methods Site characteristics and sampling}

The study was carried out at an agroforestry demonstration farm of the Christian Council of Ghana at latitude $5^{\circ} 4^{\prime} \mathrm{N}$ and longitude $0^{\circ} 21^{\prime} \mathrm{W}$ in the sub-humid transition zone that lies between the semi-deciduous and coastal savanna zones. The total annual rainfall and mean daily temperature at the study site are $1040 \mathrm{~mm}$ and 24.2 ${ }^{\circ} \mathrm{C}$, respectively. The soils of the site are developed over coarse-grained granite, and belong to the Bawjiase series (Ferric Acrisols according to FAO/ UNESCO, 1990). They are well-drained upland soils with sandy clay loam texture (Table 1).

A substantial portion of the demonstration farm comprised a pure 5-year-old woodlot of Leucaena leucocephala, var El Salvador, type K8, while an adjacent plot comprised alley farms (also 5-yearold) with maize (Zea mays L.), cowpea (Vigna unguiculata), and groundnut (Arachis hypogaea) cultivated between hedgerows of Leucaena. The size of each alley farm was about 0.3 ha. A transect, $56 \mathrm{~m}$ long, was cut within each of the alley farms and also between rows of the adjacent woodlot. Disturbed and undisturbed soil samples were collected from the 0 to $15 \mathrm{~cm}$ depth at $4 \mathrm{~m}$ interval along each transect to account for spatial variability within each landuse system. Thus, for each alley and woodlot plot, 15 soil sample replicates were obtained. The soil samples were brought to the laboratory for the analysis of selected chemical and physical properties.

\section{Laboratory investigations}

The organic carbon content of the fine earth $(<$ $2 \mathrm{~mm}$ fraction) was determined by the wet combustion method of Walkley \& Black (1934).

TABLE 1

Paricle Size Analysis of Soils under the Various Agroforestry Systems Particle size distribution (\%)

\begin{tabular}{lcccc}
\cline { 2 - 4 } System & Sand & Silt & Clay & Texture \\
\hline Woodlot & 60.0 & 15.6 & 24.4 & Sandy clay loan \\
Cowpea alley & 58.0 & 20.0 & 22.0 & Sandy clay loam \\
Maize alley & 55.5 & 20.2 & 24.3 & Sandy clay loam \\
Groundnut alley & 56.5 & 19.9 & 23.6 & Sandy clay loam
\end{tabular}


Particle size distribution was determined by the method of Day (1965). The determination of bulk density $(D)$ by the core method was impossible because of the appreciably high gravel content. Consequently, the clod method of Blake (1965), which used the undisturbed clod samples, was applied to determine bulk density. The bulk density of the soil fines, $D_{\rho}$ which excludes the gravels, was then calculated according to the procedure of Bonsu \& Laryea (1989) as follows:

$$
D_{f}=\frac{D_{t} \cdot D_{g r}\left(l-R_{\mathrm{v}}\right)}{D_{g r}-R_{w} \cdot D_{,}}
$$

where, $D_{g r}$ is the density of the gravel $(=2.65 \mathrm{Mg} /$ $\mathrm{m}^{3}$ ) and $R_{\mathrm{w}}$ is the ratio of mass of gravel to the total soil mass including gravel. Subsequently, the porosity $\left(P_{\text {, }}\right)$ of the soil matrix was calculated as follows:

$$
P_{1}=I-\left[\frac{\dot{M}_{f} \cdot D_{t}}{M_{t} \cdot D_{s}}\right]+\left[\frac{M_{g r} \cdot D_{t}}{M_{t} \cdot D_{g r}}\right]
$$

where, $M_{f}$ is the mass of the soil fines, $M_{\text {, is }}$ the total mass of soil fines plus the gravels, $M_{g r}$ is the mass of gravel, and $D_{t}$ and $D_{g r}$ are as defined in equation (1).

A modification of the water drop technique of Farres \& Cousen (1984) was used in determining aggregate stability of the soils. Twenty air-dry soil aggregates, each of diameter between 4.75 and $6.30 \mathrm{~mm}$, were selected for each alley farm and woodlot site. Each soil aggregate was placed in turns on an aggregate holder and bombarded with water drops formed from a hypodermic syringe attached to a constant head marriotte bottle positioned at a height of $2 \mathrm{~m}$ above the aggregate holder. By noting the times $\left(T_{i}\right)$ taken for the aggregates to breakdown, the percentage stability index $(S I)$ for each alley and woodlot plots was calculated as follows (Farres \& Cousen, 1984):

$$
S I=\left[\Sigma \frac{T_{i}}{T_{c}^{*}}\right] \frac{100}{N}
$$

where, $T_{c}$ is the rainstable time (s), and $N$ is the number of aggregate samples.

\section{Organic carbon}

\section{Results and discussion}

Table 2 summarizes the results of the laboratory analysis. The mean organic carbon content ranged from $13.1 \mathrm{~g} / \mathrm{kg}$ in the groundnut alley to $16.7 \mathrm{~g} / \mathrm{kg}$ in the soils under woodlot. The value for the woodlot was significantly different from

TABLE 2

Analytical Data on Selected Properties of the Soils ${ }^{+}$

\begin{tabular}{lcccc}
\hline System & $\begin{array}{c}\text { Organic } \\
\text { carbon } \\
(g / \mathrm{kg})\end{array}$ & $\begin{array}{c}\text { Bulk } \\
\text { density } \\
\left(\mathrm{Mg} / \mathrm{m}^{3}\right)\end{array}$ & $\begin{array}{c}\text { Porosity } \\
(\%)\end{array}$ & $\begin{array}{c}\text { Aggregate } \\
\text { stability } \\
(\%)\end{array}$ \\
\hline Woodlot & $16.7^{\mathrm{a}}$ & $1.16^{\mathrm{b}}$ & $54.7^{\mathrm{a}}$ & $45^{\mathrm{y}} .1^{\mathrm{a}}$ \\
Cowpea alley & $16.0^{\mathrm{ab}}$ & $1.29^{\mathrm{a}}$ & $50.3^{\mathrm{b}}$ & $17.2^{\mathrm{b}}$ \\
Maize alley & $13.5^{\mathrm{bc}}$ & $1.30^{\mathrm{a}}$ & $49.0^{\mathrm{b}}$ & $20.5^{\mathrm{b}}$ \\
Groundnut alley & $13.1^{\mathrm{b}}$ & $1.28^{\mathrm{a}}$ & $50.6^{\mathrm{b}}$ & $20.9^{\mathrm{b}}$ \\
\hline LSD $(P=0.01)$ & 2.66 & 0.09 & 2.61 & 10.41 \\
\hline
\end{tabular}

+ Values are means of 15 replicates; mean values followed by the same letters are not significantly different from each other $(P=0.01)$.

those of the alley plots. Among the alley farms, the soils under cowpea had the relatively highest mean organic carbon content, followed by those under maize and groundnut. In the woodlot system, unlike the alleys, there is no net transfer of organic material (eg. leaf litter and twigs) from the soil, until the trees are harvested. However, the constant harvesting of crops (as seeds) from the alley plots may remove some amount of organic matter from the soils, even if low. The greater accumulation of organic carbon in the soils under woodlot, therefore, may be attributed to the continuous addition of litter to the soil over the years, and also to a comparatively less frequent disturbance of the soils. Termite activity in the alley soils is high and the crop residue left directly on the surface may be destroyed by termites in a short time. Nevertheless, the contribution of organic matter by each landuse system is assessed by the biomass turnover in each system. This is currently beyond the scope of this study, but requires further investigations.

Despite the similarity in organic carbon build- 
up in the soils under the alley cropping systems, especially between maize and groundnut, the slight variations can be attributed to how each crop is harvested. Whereas cowpea is harvested by picking the pods and leaving the whole plant and roots intact for decay later, groundnut is harvested by digging up the soil to remove the whole plant and leaving the crop residue on the soil. This method of harvesting results in considerable mechanical disturbance of the soil. Although the harvesting of maize may result in limited disturbance of the soil, the decomposition of maize straw would be slower, being composed of relatively more decomposition-resistant components. These reasons, among others, may explain the subtle but observable differences in organic carbon content among the soils under the alley cropping systems.

\section{Bulk density and porosity}

The mean bulk density of the fine soil $\left(M_{p}\right)$ of all the treatment plots ranges from 1.16 to 1.30 $\mathrm{Mg} / \mathrm{m}^{3}$, with the lowest and highest values observed for the woodlot and the maize alley, respectively (Table 2 ). The mean difference between the soils under the woodlot and the alley systems was about 11 per cent. There was no significant difference among the bulk densities of soils under the three alley systems.

The relatively high bulk density for the alley plots may be partly due to their lower organic matter content and more frequent tillage. Previous evidence suggests that organic matter promotes microbial activity, which in turn results in high pore ratio and lower bulk density (Dowuona et al., 1998). Thus, the observed difference in bulk density between the woodlot and the alleys may be attributed to differences in organic matter accumulation. The variation in organic matter build-up among the alley systems was low; as a result, the differences in their bulk density values were minimal.

Table 2'also shows the mean total porosity values of the soils. The soils under the woodlot system showed the highest mean porosity value of about 55 per cent, while the maize field recorded the lowest mean porosity of about 49 per cent. Unlike Greenland (1975), who noted up to 39 per cent difference in porosity between an uncultivated and a continuously cultivated soil elsewhere, the difference observed in this study between the woodlot and alley systems was only about 7.8 per cent. Nevertheless, considering that the woodlot practice was only 5 years old, and organic matter (e.g. leaf litter and twigs) was added regularly during the period, the increase in porosity under the woodlot system is a remarkable short-term improvement in soil quality.

\section{Aggregate stability}

Table 2 also shows the aggregate stability indices $(S I)$ for the various agroforestry systems. The woodlot soils had the greatest $S I$ with a mean value of 45.2 per cent, which was about twice the values for the alley soils. However, the variation within the alley systems was minimal. Although, for the alleys the $S I$ for the cowpea soils was the least (17.2 per cent) and that for the groundnut soils was the greatest ( 20.9 per cent), the differences were not significant.

Fig. 1 shows the relation between the stability index and organic carbon content of the woodlot soils. Table 2 also indicates, as observed

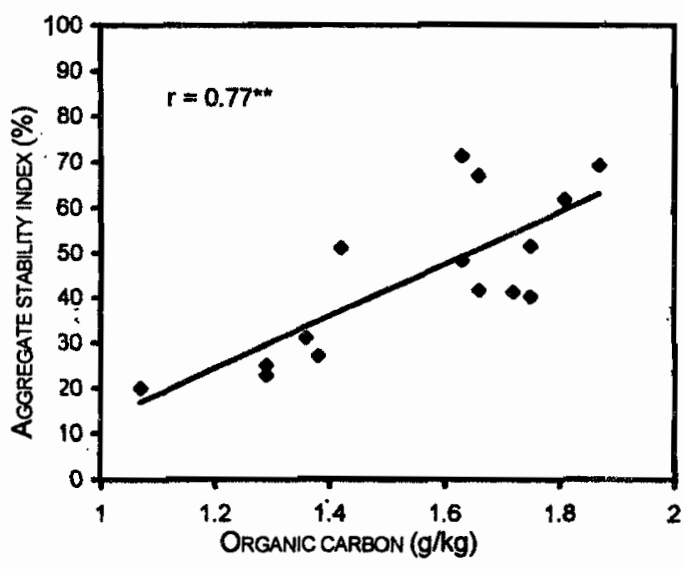

Fig. 1. Relationship between aggregate stability and organic carbon of the soils under the woodlot ${ }^{* *}=$ Significant at $P=0.01$ ). 
elsewhere (Lal, 1979), that the woodlot soils had a relatively $S I$ than the alley systems. This study attributes it to two factors. Firstly, there is a greater build-up of organic matter in the woodlot system, and as Fig. 1 shows, the aggregate stability index of the woodlot correlated well with organic matter $\left(r=0.77^{* *}\right)$. This study did not have a good correlation between $S I$ and organic carbon content for the alley system. Secondly, there is a lower frequency of tillage under the woodlot system.

Moreover, it has been observed that seasonal cultivation of soils under the alley systems tends to reduce aggregation through mechanical rupture of peds, resulting in a reduction in organic matter and associated action of microbial exudates (Pritchett, 1979). On the other hand, the stabilizing effects of organic matter on soil aggregation and structure are well known and documented (Greenland, Ligtrom\& Quirk, 1962; Lal, 1979; TeteMensah, 1993; Dowuona et al., 1998). Although it is also known that clay can improve aggregate stability, the uniformity in the clay content of these soils (Table 1) seems to suggest that the observed differences in aggregate stability among the soils may be more attributed to the differences in organic matter accumulation. The advantage of this relationship is that data on organic matter content of soils can be used to estimate the stability of soil aggregates, and thus provide information for their efficient use and management.

\section{Conclusion}

This study sought to evaluate the effects of agroforestry systems on some soil properties. Of the systems considered, the woodlot showed the highest organic matter build-up, aggregate stability and porosity, and the least bulk density. The difference between the observations made for the woodlot and the other systems was significant. Variations between the alley systems in soil properties were minimal. Hence, compared to a woodlot system, alley cropping was apparently not a better system in improving or maintaining soil tilth.
The key issue in managing good soil tilth and perhaps also fertility seems to hinge on managing organic matter and reducing mechanical tillage. This view may give credence to the traditional system of shifting cultivation which allows the soil to be "rested" for some time before recultivation. However, considering the problems of pressure on land, it is proposed that a rotation of alley farming and woodlot systems will ensure sustainable soil productivity. This would then reduce the fallow period to allow the alley hedgerows to grow into woodland before the alley crops are replanted. However, further research is needed to establish this relationship. The stability of soil aggregates may be estimated from data on organic matter content.

\section{Acknowledgement}

The authors wish to thank the Development and Environment Department of the Christian Council of Ghana for the use of their agroforestry site. Partial financial assistance from the National Agricultural Research Project (NARP) is also appreciated.

\section{REFERENCES}

Blake, G. K. (1965) Bulk density. In Methods of soil analysis, No. 9 Part 2 (ed. C. A. Black), pp. 545567. Madison, Wisconsin, American Society of Agronomy.

Bonsu, M. \& Laryea, K. B. (1989) Scaling the saturated hydraulic conductivity of an Alfisol. J. Soil Sci. 40, 731-742.

Day, P. R. (1965). Particle size fraction and particle size analysis. In Methods of soil analysis, Part 1 (ed. C. A. Black), pp. 55-565. Madisón, Wisconsin, American Society of Agronomy.

Dowuona, G. N., Mermut, A. R., Adiku, S. G. K., Nartey, E. \& Tete-Mensah, I. (1998) Improvements in the quality of soils under agroforestry practice in Ghana. In Soil fertility management in West African land use systems (ed. G. Renard, A. Neef, K. Baker and M. von Oppen), pp. 251-258. Margraf Verlag, Filderstat, Germany. FAO-UNESCO (1990) Soil map of the world. Revised Legend. Rome, FAO. 
Farres, P. J. \& Cousen, S. M. (1984) An improved method of aggregate stability measurement. Earth Surf. Processes Landforms 10, 321-329.

Greenland, D. J. (1975) Soil structure and erosion hazard. In Soil conservation and management in the humid tropics (ed. P. A. Sanchez). NewYork, John Wiley and Sons, pp. 17-23.

Greenland, D. T., Ligtrom, G. R. \& Quirk, J. P. (1962) Organic materials which stabilize natural soil aggregates. Soil Sci. Soc. Am. Proc. 26, 366-371.

Lal, R. (1979) Effect of cultural and harvesting practices on soil physical conditions. In Soil research in agroforestry (ed. H. O. Mongi and P. A. Huxley), pp. 327-351, Nairobi, ICRAF.

Nair, P. K. R. (1984) Soil productivity aspect of agroforestry: Science and practice of agroforestry.
Nairobi, ICRAF.

Tete-Mensah, I. (1993) Evaluation of some physical and chemical properties of soils under two agroforestry practices (M Phil Thesis). Department of Soil Science, University of Ghana, Legon, $73 \mathrm{pp}$.

Pritchett, W. L. (1979) Properties and management of forest soils. New York, John Wiley and Sons.

Walkley, A. \& Black, I. A. (1934) An examination of the Degtjareff method for determining soil organic matter and a proposed modification of the chromic acid titration method. Soil Sci. 37, 29-38.

Weert, R. van der \& Lenselink, K. J. (1972) The influence of mechanical clearing of forest on some physical and chemical properties. Surinamese Landbouw 20 (3), 2-14. 